\title{
Brazilian Protocol for Sexually Transmitted Infections, 2020: infections causing vaginal discharge
}

\author{
Newton Sergio de Carvalho ${ }^{[1]}$, José Eleutério Junior ${ }^{[2]}$, Ana Gabriela Travassos ${ }^{[3]}$, \\ Lutigardes Bastos Santana ${ }^{[4]}$ and Angélica Espinosa Miranda ${ }^{[4],[5]}$
}

\author{
[1]. Universidade Federal do Paraná, Departamento de Tocoginecologia, Curitiba, PR, Brasil. \\ [2]. Universidade Federal do Ceará, Departamento de Saúde da Mulher, da Criança e do Adolescente, Fortaleza, CE, Brasil. \\ [3]. Universidade do Estado da Bahia, Departamento de Ciências da Vida, Salvador, BA, Brasil. \\ [4]. Ministério da Saúde, Secretaria de Vigilância em Saúde, Brasília, DF, Brasil. \\ [5]. Universidade Federal do Espírito Santo, Departmento de Medicina Social, Vitoria, ES, Brasil.
}

\begin{abstract}
The topic of vaginal discharge is one of the chapters of the Clinical Protocol and Therapeutic Guidelines for Comprehensive Health Care for People with Sexually Transmitted Infections, published by the Brazilian Ministry of Health in 2020. The chapter has been developed based on scientific evidence and validated in discussions with specialists. This article presents epidemiological and clinical aspects associated with vaginal discharge conditions, as well as guidance to health service managers and health professionals. Screening, diagnosing, and treating these conditions, the main complaints among women seeking health services, caused by infectious or noninfectious factors, also are presented. Besides, information is presented on surveillance, prevention, and control actions to promote knowledge of the problem and provide quality care and effective treatment.
\end{abstract}

Keywords: Vaginitis. Candidiasis. Vulvovaginal. Vaginosis. Bacterial. Trichomonas Infections. Sexually transmitted diseases.

Highlighted excerpt: In healthcare servicing cases of sexually transmitted infections, vaginal discharge is the main referred symptom, common among pregnant women.

\section{INTRODUCTION}

This article approaches the chapter on infections causing vaginal discharge in the Clinical Protocol and Therapeutic Guidelines for Comprehensive Health Care (PDCT) for People with Sexually Transmitted Infections (STI), published by the Health Surveillance Department of the Brazilian Ministry of Health. For elaborating the PCDT, a selection and analysis of the evidence available in the literature were performed, and a panel of specialists discussed it. The document was approved by the National Committee for Technology Incorporation to the Brazilian National Health System (Conitec) and updated by the team of specialists in STI in $2020^{1}$.

\footnotetext{
Corresponding author: Angélica Espinosa Miranda.

e-mail: angelica.miranda@ufes.br

(D) https://orcid.org/0000-0002-5556-8379

Received 01 February 2021

Accepted 10 March 2021
}

\section{EPIDEMIOLOGICAL ASPECTS}

In clinics addressing STI cases, vaginal discharge is the main referred symptom ${ }^{2-4}$, being also a frequent complaint in pregnant women ${ }^{5-7}$. Non-infectious causes of vaginal discharge include excessive elimination of physiological mucous material, presence of intravaginal foreign objects, and atrophic vaginitis. It can occur in women after menopause, during breastfeeding, or as an effect of local radiotherapy in oncology treatment ${ }^{4,7,8}$. Other situations can cause vulvovaginal pruritus without discharge, such as allergic or irritant dermatitis (soap, perfume, and latex) or skin diseases (atopic dermatitis, lichen, and psoriasis ${ }^{8}$.

Among the infectious causes of vaginal discharge, women can simultaneously present infection by more than one etiologic agent, which causes nonspecific aspect discharge ${ }^{4}$. The agents can be associated with vaginitis or vaginosis, depending on the existence or nonexistence of the inflammatory process. These are conditions of the vulvovaginal stratified epithelium. The most frequent etiologic agents are fungi (mainly Candida albicans), anaerobic bacteria associated with bacterial vaginosis, and protozoan Trichomonas vaginalis. There can also be cytolytic vaginosis, dysbiosis arising from a significant increase in lactobacilli and the lytic action on squamous cells ${ }^{4,9}$, and the possibility of mixed vaginitis. 
C. albicans is the etiological agent of vulvovaginal candidiasis in $80 \%$ to $92 \%$ of cases; non-albicans species (Candida glabrata, Candida tropicalis, Candida krusei, Candida parapsilosis) and Saccharomyces cerevisae are less prevalent ${ }^{9}$. Over reproductive life, 10 to $20 \%$ of women will be colonized by Candida $s p$. in an asymptomatic way, not requiring treatment, as yeast can be part of the vaginal environment ${ }^{10,11}$. Among factors predisposing vulvovaginal candidiasis, the ones indicated in Figure $\mathbf{1}$ are highlighted. Vulvovaginal candidiasis is classified as non-complicated and complicated. The first one occurs when all following criteria are present: mild/moderate symptoms and rare frequency; C. albicans as an etiologic agent; and lack of comorbidities. Complicated vulvovaginal candidiasis takes place when at least one of the following criteria are present: intense symptoms; recurrence of four or more episodes in a year; non-albicans etiologic agent $(C$. glabrata, C. kruzei); presence of comorbidities such as diabetes and human immunodeficiency virus, HIV; or pregnancy ${ }^{4,11}$. Most vulvovaginal candidiasis is not complicated and respond to different treatments. Nevertheless, we observe the recurrent form of this disease in $5 \%$ of women ${ }^{11,12}$.

Bacterial vaginosis is the most frequent abnormality in the lower genital tract among women in reproductive age. It is the most prevalent cause of vaginal discharge with fetid odor. It is associated with the reduction of lactobacillus and the growth of several anaerobic and facultative bacteria, such as Gram-variable short bacilli, short Gram-negative bacilli, and anaerobic Gramnegative cocci, with variation, mainly Gardnerella, Atopobium, Prevotella, Megasphaera, Leptotrichia, Sneathia, Bifidobacterium, Dialister, Mobiluncus, Ureaplasma, Mycoplasma and three species of Clostridium known as bacterial vaginosis associated bacteria, BVAB 1 to $3^{13}$. Certain changes in vaginal microbiome (dysbiosis) can be associated to higher frequency of bacterial vaginosis. A study on the characteristics of Brazilian women's microbiome in reproductive age showed the microbiome type (communitystate types, CST) corresponding to CST IV, with depletion of lactobacillus and growth in vaginal $\mathrm{pH}$ in $27.4 \%$, with bacterial vaginosis present in $79.6 \%$ of the cases ${ }^{14}$.

Trichomonas infections are the most common non-viral STI, being present in 140 million people in the world. A flagellated parasite causes it, T. vaginalis $^{15}$, that causes changes to the vaginal microbiome, growth of local inflammatory response, and relevant reduction in the number of Lactobacillus sp. Trichomonas infections are associated with an increasing of the probability of HIV transmission ${ }^{16}$.

In some cases, there is a growth of lactobacillus, with great destruction of intermediate squamous cells (cytolysis), associated with genital irritative symptoms ${ }^{17}$. It is cytolytic vaginosis, a situation that is usually cyclic in women in reproductive years ${ }^{16}$, with a prevalence of $1 \%$ to $7 \%$, most frequent for 25 and 40 years ${ }^{17,18}$.

Mixed vaginitis is a condition in which two pathogens are causing vulvovaginal symptoms. They can be pathogens with vaginal $\mathrm{pH}$ preferences equal to or not to one another. There can be, for example, vaginitis caused by $T$. vaginalis associated with bacterial vaginosis ${ }^{19}$. Notwithstanding, the most frequent form of mixed vaginosis is the association of Candida infection with bacterial vaginosis. Its frequency varies between $7 \%$ and $22 \%$ of vaginal discharge cases, depending on the diagnosis method used ${ }^{20}$.

\section{CLINICAL ASPECTS}

Vaginal infection and dysbiosis can be associated with different discharge forms, pruritus, irritation, and pain ${ }^{21}$. Hence, it is essential always to identify, in anamnesis, aspects related to consistency, color, and modifications in vaginal discharge, in addition to the presence of pruritus, local irritation and smell. The investigation of clinical history must be detailed, encompassing information on sexual behavior and practices, date of last menstrual period, vaginal hygiene practices, use of topical or systemic medication and other possible local irritating agents, in addition to comorbidities such as

\begin{tabular}{|l|}
\hline Pregnancy \\
\hline Obesity \\
\hline Diabetes mellitus (unbalanced) \\
\hline Corticosteroid medication use \\
\hline Antibiotic medication use \\
\hline Use of oral contraceptives \\
\hline Use of immunosuppressors or chemo/radiotherapy \\
\hline Changes in immune response (immunodeficiency) \\
\hline Hygiene and clothing habits increasing local humidity and heat \\
\hline Contact with allergenic and irritating substances (ex.: genital powder, perfume, soap or deodorant) \\
\hline HIV infection \\
\hline
\end{tabular}

Source: adapted from the Clinical Protocol and Therapeutic Guidelines for Comprehensive Health Care for People with Sexually Transmitted Infections, 202022.

FIGURE 1: Factors predisposing vulvovaginal candidiasis. 
diabetes and HIV infection ${ }^{22}$. During the gynecologic examination, the healthcare professional must identify characteristics of vaginal flow as observed in speculum examination and alterations present, such as inflammation (colpitis), ulcer, edema, and erythema ${ }^{22}$.

\section{Vulvovaginal candidiasis}

Characteristic signs of vulvovaginal candidiasis are erythema, vulvar fissures, clumpy discharge, white plates stuck to the vaginal wall, vulvar edema, excoriations, etc., satellite lesions, which can become pustules through intense scratching ${ }^{8}$. Usually, there is an association between vaginitis and vulvitis, although such conditions can also take place separately. Clinically, vulvovaginal candidiasis can associate with vaginal introitus dyspareunia and external dysuria due to irritation and local lesions ${ }^{21}$.

\section{Bacterial vaginosis}

On the other hand, in bacterial vaginosis, women present homogeneous and fluid vaginal discharge, frequently with fetid odor. Unbalances in the vaginal microbiome have been identified as an alteration often associated with some STIs, including HIV, complications in gynecological surgeries, and pregnancy (premature rupture of membrane, chorioamnionitis, prematurity, and post-cesarean endometritis). When it is present during invasive procedures, such as uterine curettage, endometrial biopsy, and insertion of an intrauterine device (IUD), bacterial vaginosis can increase pelvic inflammatory disease risk $^{13}$. The condition has also been associated with higher risk of human papillomavirus (HPV), and precancerous cervical lesions ${ }^{23}$. The reduction of commensal lactobacillus is associated with increased vaginal $\mathrm{pH}$ and the growth of anaerobic microbiota, with amino production (putrescine, cadaverine, and trimethylamine) that become volatile when mixed with substances of alkaline $\mathrm{pH}$, releasing these enzymes to the environment and producing an unpleasant odor. This situation happens particularly after intercourse and menstruation (which alkalinizes vaginal contents), contributing to women's main complaint. In speculum examination, we can observe that the vaginal walls are brown, most integral, and homogeneous to Schiller's test, bathed in pearly bubbly discharge ${ }^{24}$.

\section{Trichomonas infections}

Signals and symptoms of trichomonas infections are comprised of greenish-yellow, sometimes grayish, bubbly, and foamy intense vaginal discharge, with fetid odor and possible pruritus. It can occur bleeding in sexual intercourse and dyspareunia associated with the inflammatory process in more serious cases. It can also occur vulvar edema and urinary symptoms, such as dysuria ${ }^{25}$. Most of the cases of trichomonas infections are asymptomatic and stay without diagnosis or treatment ${ }^{26}$. Although the process is not entirely comprehended, and the protozoan can make easier the transmission of other more aggressive infectious agents, facilitate the evolution to pelvic inflammatory disease and bacterial vaginosis. In pregnancy, when it is not treated, it can be associated with premature rupture of the membranes ${ }^{27}$. In speculum examination, microulcerations are commonly seen in the cervix, similarly to the aspect of a strawberry or raspberry (Schiller's test with "tiger" or "leopard" aspect). Trichomonas infections can be associated with bacterial vaginosis in an anaerobic environment, with amines being volatilized with its suggestive odor ${ }^{15}$.

\section{Cytolytic vaginosis}

In cases of cytolytic vaginosis, at first, the symptoms are very similar to the ones for vulvovaginal candidiasis, when the woman refers to genital irritation associated with a white to yellowish-white vaginal discharge with lumps, but frequently with cyclic behavior? Speculum examination shows white, milky, and lumpy vaginal content stuck to the vaginal walls. Vaginal $\mathrm{pH}$ is presented as lower than 4.5 , and the test for amines shows negative ${ }^{18}$. On the other hand, in mixed vaginitis, the clinical picture varies, depending on the agents encompassed. In bacterial vaginosis and candidiasis, both odorous discharge and genital pruritus can be the chief complaint ${ }^{19}$.

\section{DIAGNOSIS}

Clinical management of women with vaginal discharge is presented in Figure 2. For diagnosis clarification of the agents causing vaginal flow, we need anamnesis and supplementary examinations ${ }^{19}$.

\section{Vulvovaginal candidiasis}

Vulvovaginal candidiasis diagnosis must be confirmed through laboratory examinations. The simplest one is the microscopic examination of fresh vaginal content. In this procedure, a sample of the material collected from the vaginal wall is placed on a plate. One to two drops of saline or $10 \%$ potassium hydroxide for better evidencing morphotypes of yeasts are added ${ }^{28}$. In addition to this examination, another simple method and low-cost is the Gram-stained vaginal smear bacterioscopy ${ }^{29}$. In cases of recurrent candidiasis, a culture for fungi can be needed (Sabouraud, Nickerson's, or Microstix-Candida media) in a vaginal sample, aiming at identifying the species of fungi ${ }^{30}$. For a differential diagnosis of recurrent vulvovaginal candidiasis, we must consider lichen sclerosus, vulvar vestibulitis, vulvar dermatitis, vulvodynia, cytolytic vaginitis, desquamative inflammatory vaginitis, atypical forms of genital herpes, and hypersensitivity reactions ${ }^{11}$.

\section{Bacterial vaginosis}

Bacterial vaginosis diagnosis is based on Amsel's criteria ${ }^{31}$, with the need for the diagnosis, complying with three of the four following criteria: $\mathrm{pH}$ higher than 4,5; grayish and homogeneous vaginal discharge; positive amine discharge; and identification of clue cells in microscopic examination. The Nugent score has replaced this diagnosis criterion ${ }^{13,32}$. Both criteria can be associated, although the gold pattern is the Nugent laboratory procedure, using Gram staining and objective score system, indicated as evidence II- $2^{32,33}$. This evaluation attributes a score for three morphotypes: lactobacilli, Gram-variable coccobacilli, and Gram-negative curved bacilli. After the sum of all agents' scores, 7-10 indicates bacterial vaginosis, 4-6 is intermediate, and 0-3 is normal ${ }^{32}$ (Figure 3).

\section{Trichomonas infections}

In trichomonas infections, the most used laboratory microbiological diagnosis in clinical practice is the microscopic examination of fresh vaginal content in saline, observing the 


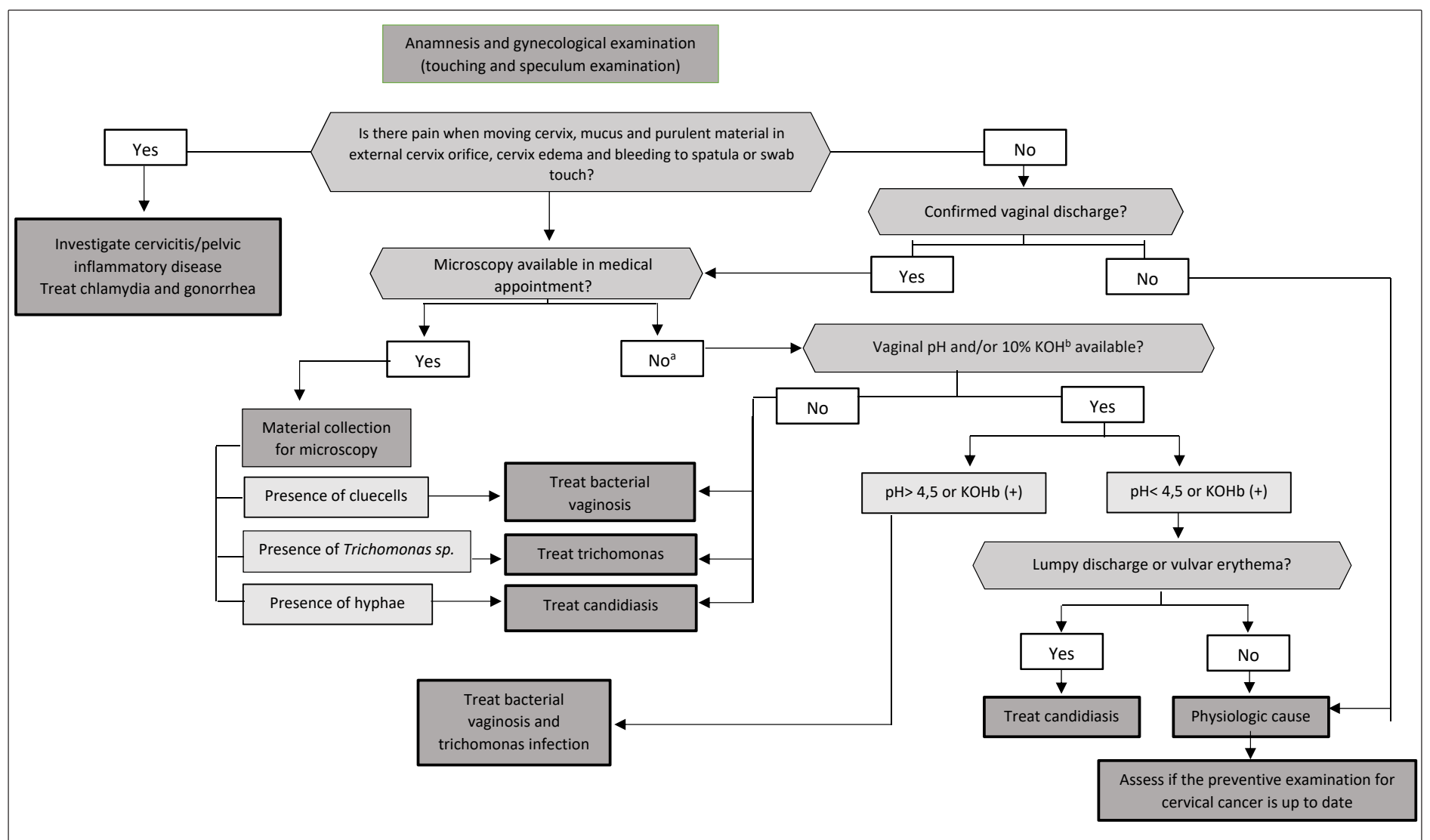

Source: adapted from the Clinical Protocol and Therapeutic Guidelines for Comprehensive Health Care for People with Sexually Transmitted Infections, $2020^{22}$. Note: a) When the collection is conducted for microscopy through Gram-staining, consider the result for managing the case; b) potassium hydroxide.

FIGURE 2: Recommendations for handling vaginal discharge.

\begin{tabular}{|c|c|c|c|c|}
\hline Score ${ }^{a}$ & Lactobacilli & $\begin{array}{c}\text { Gardnerella, } \\
\text { Bacteroides, etc. }\end{array}$ & Curved bacilli & $\begin{array}{l}\text { Quantification of bacteria } \\
\text { in a plate (Gram-staining) }\end{array}$ \\
\hline 0 & $4+$ & 0 & 0 & $\begin{array}{c}0 \\
\text { Absence of bacteria }\end{array}$ \\
\hline 1 & $3+$ & $1+$ & $1+$ or $2+$ & $\begin{array}{c}1+ \\
<1 \text { bacteria/field }\end{array}$ \\
\hline 2 & $2+$ & $2+$ & $3+$ or $4+$ & $\stackrel{2+}{2+}$ \\
\hline 3 & $1+$ & $3+$ & - & $\begin{array}{c}3+ \\
6 \text { to } 30 \text { bacteria/field }\end{array}$ \\
\hline 4 & 0 & $4+$ & - & $\begin{array}{c}4+ \\
\text { >30 bacteria/field }\end{array}$ \\
\hline
\end{tabular}

Source: Clinical Protocol and Therapeutic Guidelines for Comprehensive Health Care for People with Sexually Transmitted Infections 202022.

Note: Result interpretation: 0 to 3 - negative for bacterial vaginosis; 4 to 6 - changed microbiota; 7 or more - bacterial vaginosis.

FIGURE 3: Nugent score for bacterial vaginosis diagnosis. 
parasite in the microscope. The protozoan movement, a flagellated one, can be seen, as well as a significant number of leukocytes. $\mathrm{pH}$ is almost always higher than $5.0^{29}$. In most cases, the test for amines is positive, and we can observe Gram-negative bacteria in bacterioscopy when there are tests for diagnosis with Gramstaining. On the other hand, T. vaginalis is a flagellated protozoan stained through Papanicolaou or Giemsa techniques. Culture can be requested in cases of challenging diagnosis. Culture media vary, and they can include Diamond's, Trichosel, and InPouch TV ${ }^{34}$. The diagnosis can also be conducted with molecular biology through a polymerase chain reaction, $\mathrm{PCR}$, including multiplex tests that can detect more than one pathogen and allow for identifying even asymptomatic cases ${ }^{15}$, due to its high sensitivity.

The current pattern of diagnosis test for vulvovaginitis depends on the structure available at the place of attendance. Most of the diagnoses are conducted empirically and based on clinics, although the availability of a microscope for fresh examination is an important supplementary examination. Molecular tests directed to bacterial vaginosis diagnosis, Candida sp. and $T$. vaginalis can improve diagnostic accuracy and reduce result time compared to culture $^{35,36}$. This can be especially important for bacterial vaginosis, which encompasses multiple organisms in vaginal microbiota ${ }^{37}$.

\section{Cytolytic vaginosis}

Cytolytic vaginosis diagnosis must comply with the following criteria: white discharge, pruritus or genital burning, vaginal $\mathrm{pH}$ between 3.5 and 4.5, and examination of fresh vaginal content without any pathogen, with identification of a significant population of medium bacilli, some naked nuclei, and cell detritus ${ }^{38}$. Gram bacterioscopy and Papanicolaou examination can present the same microscopic findings ${ }^{22}$.

In cases of mixed vaginitis, the presence of two microorganisms in the same moment not necessarily implies that both are pathogenic, especially when it comes to bacterial vaginosis and vulvovaginal candidiasis, considering that both yeast and bacteria in bacterial vaginosis not always cause the disease. Therefore, it is important to differentiate between mixed vaginitis and co-occurrence ${ }^{18}$. In the first case, both the agents are pathogenic, which does not necessarily occur in the second case, as the change in the vaginal microbiome can be the agent causing a recurrence. More advanced methods, such as PCR, can lead to inconclusive results if they are not correctly interpreted. Cases with bacterial vaginosis criteria presenting identified inflammatory infiltration were sometimes identified as suggesting a picture of mixed vaginitis ${ }^{39}$. The association can be observed using fresh examination, bacterioscopy, cytology, or molecular biology ${ }^{40}$.

\section{Treatment}

Options for treating the vulvovaginitis caused by Candida, bacterial vaginosis, and trichomonas infections are described in Figure 4. It is crucial to suspend sexual relations to prevent contaminations during treatment, which must be kept during the menstrual period. In the treatment with metronidazole, drinking alcoholic beverages must be avoided, due to the antabuse effect, caused by the interaction with imidazole derivatives with alcohol and characterized by discomfort, nausea, vertigo, and a metallic taste in the mouth ${ }^{22}$.
Cytolytic vaginosis is treated through using sodium bicarbonate ${ }^{38}$ in vaginal baths $(15 \mathrm{~g}$ to $30 \mathrm{~g}$ of sodium bicarbonate in $0.5 \mathrm{~L}$ of warm water), twice to three times a week, for two to six weeks ${ }^{18}$. The treatment on cases of mixed vaginitis uses concomitant therapy for each of the pathogens. In case of candidiasis and vaginosis, using antifungal medications with metronidazole is recommeded ${ }^{19}$.

It is essential to highlight that trichomonas infections can change the evaluation of oncological cytology. In cases in which cellular morphological alterations and trichomonas infections, the treatment must be conducted, and the cytology repeated after three months to identify if the changes persist ${ }^{22}$. In recurrent bacterial vaginosis, the triple regime (use of metronidazole cream for ten days, followed by boric acid for 21 days and maintenance with metronidazole cream twice a week, for four to six months) seems successful albeit requiring validation by randomized and controlled clinical assays. The role of boric acid is to remove the bacterial biofilm formed on the vaginal wall that facilitates the persistence of such a picture ${ }^{41}$.

In the vulvovaginal candidiasis cases that are recurrent or difficult to control, we must investigate predisposing systemic causes, such as diabetes, immunodepression (including HIV infection), and the use of corticosteroids. Among the rare adverse reasons $(0.01 \%$ to $0.1 \%$ ) of fluconazole use, we can cite agranulocytosis, leukopenia, neutropenia, thrombocytopenia, anaphylaxis, angioedema, hypertriglyceridemia, hypercholesterolemia, hypokalemia, toxicity, and hepatic insufficiency; for this reason, it is essential to investigate liver functioning ${ }^{29}$.

There is no recommendation for screening bacterial vaginosis in asymptomatic women. The treatment is recommended for all symptomatic women with the potential risk of complications, as before IUD insertion, gynecological surgeries, and invasive examinations of the genital tract. The treatment must be simultaneous to the procedure, with no reason for suspension or delay ${ }^{22}$. Recurrence of bacterial vaginosis after treatment is common: around $15 \%$ to $30 \%$ of women present symptoms for the period of 30 to 90 days after antibiotics therapy, while $70 \%$ of women experience a recurrence within nine months ${ }^{42,43}$. Some factors justify the lack of therapeutic response to the conventional schemes; among them, frequent sexual activity with no use of condoms, vaginal douche, UID use, improper immune response, and bacterial resistance to imidazole medication. Strains of Atopobium vaginae resistant to metronidazole medication are identified in different women with recurrent bacterial vaginosis; however, such bacilli are sensible to clindamycin and cephalosporins ${ }^{22,41}$.

The recurrence of infection by $T$. vaginalis, whose cause is still not clear, occurs between $5 \%$ and $31 \%$ of treated women. We need to assess the partner's treatment, the exposure to new partners, and, finally, the therapeutic failure ${ }^{44}$. Treatment with a single dose and the presence of HIV infection seem to be the factors most associated with therapeutic failure ${ }^{45}$. The molecular mechanism of clinical resistance by $T$. vaginalis is not clear ${ }^{44}$.

In the follow-up of women with Candida infections, we can observe an increased frequency of recurrences in the presence of changes in cell immunity, such as in women living with HIV 


\begin{tabular}{|c|c|c|}
\hline Clinical condition & Treatment & Notes \\
\hline \multicolumn{3}{|l|}{ Vulvovaginal candidiasis } \\
\hline First option & $\begin{array}{l}2 \% \text { Miconazole cream or other imidazole derivatives, vaginal route, one full } \\
\text { applicator, at night when going to bed, for seven days OR IU } 100,000 \text { Nystatin, } \\
\text { one application, vaginal route, at night, when going to bed, for } 14 \text { days }\end{array}$ & \multirow{3}{*}{$\begin{array}{l}\text { Sexual partners do not need to be treated, } \\
\text { except symptomatic ones. } \\
\text { It is common during pregnancy, and there } \\
\text { can be recurrence due to the favorable } \\
\text { conditions of vaginal pH in this period. }\end{array}$} \\
\hline Second option & $\begin{array}{l}\text { Fluconazole } 150 \mathrm{mg} \text {, per os (PO), single dose OR Itraconazole } 100 \mathrm{mg} \text {, two } \\
\text { pills, PO, twice/day, for one day }\end{array}$ & \\
\hline $\begin{array}{l}\text { Complicated and recurrent } \\
\text { vulvovaginal candidiasis }\end{array}$ & $\begin{array}{l}\text { Induction: fluconazole } 150 \mathrm{mg}, \mathrm{PO} \text {, once/day, in days } 1,4 \text { and } 7 \text { OR } \\
\text { Itraconazole } 100 \mathrm{mg} \text {, two pills, PO, twice/day, for one day OR Miconazole } \\
\text { topical vaginal cream daily for } 10-14 \text { days } \\
\text { Maintenance: fluconazole } 150 \mathrm{mg}, \mathrm{PO} \text {, once/week for six months OR } \\
\text { Miconazole topical vaginal cream, twice/week OR Miconazole vaginal ovule, } \\
\text { once/week for six months }\end{array}$ & \\
\hline \multicolumn{3}{|l|}{ Bacterial vaginosis } \\
\hline $\begin{array}{l}\text { The first option } \\
\text { (including pregnant and } \\
\text { breastfeeding women) }\end{array}$ & $\begin{array}{l}\text { Metronidazole } 250 \mathrm{mg} \text {, two pills } \mathrm{PO} \text {, twice/day for seven days OR } \\
\text { Metronidazole cream, vaginal use } 100 \mathrm{mg} / \mathrm{g} \text {, one full applicator vaginal route, } \\
\text { at night when going to bed, for five days }\end{array}$ & \multirow{3}{*}{$\begin{array}{l}\text { The treatment of sexual partners is not } \\
\text { recommended. For postpartum women, } \\
\text { we recommend the same treatment as for } \\
\text { pregnant women. }\end{array}$} \\
\hline Second option & Clindamycin 300mg, PO, twice/day, for seven days & \\
\hline Recurrent & $\begin{array}{l}\text { Metronidazole } 250 \mathrm{mg} \text {, two pills } \mathrm{PO} \text {, twice/day, for } 10-14 \text { days } \mathrm{OR} \\
\text { Metronidazole cream, vaginal use } 100 \mathrm{mg} / \mathrm{g} \text {, one full applicator, vaginal route, } \\
\text { once/day, followed by suppressive treatment with intravaginal boric acid ovule } \\
\text { of } 600 \mathrm{mg} \text { per day for } 21 \text { days and metronidazole, vaginal use } 100 \mathrm{mg} / \mathrm{g} \text {, twice/ } \\
\text { week, for } 4-6 \text { months }\end{array}$ & \\
\hline \multicolumn{3}{|l|}{ Trichomonas infections } \\
\hline \multirow[t]{2}{*}{$\begin{array}{l}\text { The first option } \\
\text { (including pregnant and } \\
\text { breastfeeding women) }\end{array}$} & \multirow[t]{2}{*}{$\begin{array}{l}\text { Metronidazole } 400 \mathrm{mg} \text {, } 5 \text { pills PO, single dose (total dose } 2 \mathrm{~g} \text { ) OR } \\
\text { Metronidazole } 250 \mathrm{mg} \text {, two pills, PO, twice/day, for seven days }\end{array}$} & $\begin{array}{l}\text { Sexual partners must be treated with the } \\
\text { same therapy scheme. The treatment can } \\
\text { assess symptoms of vaginal discharge in } \\
\text { pregnant women and prevent infection in } \\
\text { newborns. }\end{array}$ \\
\hline & & $\begin{array}{l}\text { For postpartum women, we recommend the } \\
\text { same treatment as for pregnant women. }\end{array}$ \\
\hline
\end{tabular}

Source: adapted from the Clinical Protocol and Therapeutic Guidelines for Comprehensive Health Care for People with Sexually Transmitted Infections, $2020^{22}$.

FIGURE 4: Treatment of vulvovaginal candidiasis, bacterial vaginosis, and trichomonas infections.

or diabetes and those with Candida non-albicans infections. In combination with behavioral changes, prolonged treatment has been used with some response in the treatment of recurrences ${ }^{46}$. The etiological diagnosis is vital in recurrence cases, aiming at identifying the species present and confirm fungal infection, considering the existence of differential diagnoses such as cytolytic vulvovaginitis, allergic reactions, and mixed infections ${ }^{47}$.

\section{SURVEILLANCE, PREVENTION, AND CONTROL}

STI diagnosis, different from endogenous and iatrogenic infections, implies the need for guidance and treatment of sexual partners. It is essential to assess the woman's perception of the existence of physiological vaginal discharge and recommend investigating other $\mathrm{STI}^{22}$.
The treatment of sexual partners, when recommended, must be conducted ideally face-to-face, with the due guidance, request of examinations for diagnosis of other STI and identification, summoning and treatment of other different sexual partners, aiming at blocking the chain of infection ${ }^{22}$. In trichomonas infections, as it is an STI, we recommend treating the sexual partners with the same therapeutic scheme as the diagnosed case ${ }^{47}$. In cases of bacterial vaginosis, the sexual partners do not need to be treated. In situations of vulvovaginal candidiasis, the partners only need to be treated if they present symptoms. However, we need to emphasize the role of counseling to the sexual partners ${ }^{22}$.

Cases of infections causing vaginal discharge do not present compulsory notification at the national level, and trichomonas infections can be included, if it is considered convenient, in the list of reports of municipalities and states. 


\section{SPECIAL POPULATIONS}

\section{Pregnant women}

Vulvovaginal candidiasis is common during pregnancy, and there can be recurrence due to the favorable conditions of vaginal $\mathrm{pH}$ in this period. The treatment in pregnant and breastfeeding women must be conducted only through the vaginal route. Oral treatment and the use of triazole medications is contraindication ${ }^{22,48}$. Although a systematic review showed a lack of benefits in tracing bacterial vaginosis in asymptomatic pregnant women ${ }^{49}$, other studies showed advantages when the disease is associated with other agents ${ }^{50}$. Despite being controversial, there are suggestions for the treatment of asymptomatic pregnant women. The benefit is defined for those with preterm delivery history with comorbidities.

\section{HIV infections}

The treatment must be conducted with the usual schemes for vulvovaginal candidiasis, bacterial vaginosis, and trichomonas infections ${ }^{22}$, but drug interaction between metronidazole and ritonavir must be observed which can increase nausea and vomit occurrence, reducing antiretroviral adherence. To avoid this occurrence, we recommend a two-hour interval between the administrations of both medications. Bacterial vaginosis has also been observed to provide a set of microorganisms that can increase the levels of viral copies of genital HIV and make vulvovaginal candidiasis episodes more severe and complicated ${ }^{51}$.

\section{ACKNOWLEDGMENTS}

The authors acknowledge this article's contribution by the members of the technical group of specialists responsible for developing the PDCT for Comprehensive Health Care for People with STI 2020.

\section{ORCID}

Newton Sergio de Carvalho - 0000-0001-7561-4566

José Eleutério Junior - 0000-0003-4617-7269

Ana Gabriela Travassos - 0000-0001-9242-828X

Lutigardes Bastos Santana - 0000-0003-0394-0113

Angélica Espinosa Miranda - 0000-0002-5556-8379

\section{Authors' contributions}

Carvalho NS, Eleutério Junior J, Travassos AG, Santana LB, and Miranda AE contributed with the conception, designing, writing, and critical review of the manuscript. The authors approved the final version of the article and are responsible for all aspects, including the assurance of accuracy and integrity.

\section{REFERENCES}

1. Brasil. Ministério da Saúde.Portaria MS/SCTIE no 42, de 5 de outubro de 2018. Torna pública a decisão de aprovar o Protocolo Clínico e Diretrizes Terapêuticas para Atenção Integral às Pessoas com Infecções Sexualmente Transmissíveis (IST), no âmbito do Sistema Único de
Saúde - SUS [Internet]. Diário Oficial da União, Brasília (DF), 2018 Oct 8 [cited 2020 Sep 4];Seção I:88. Available from: http://bvsms.saude.gov. br/bvs/saudelegis/sctie/2018/prt0042_08_10_2018.html

2. Bastos LM, Passos MR, Tiburcio AS. Gestantes atendidas no setor de doenças sexualmente transmissíveis da Universidade Federal Fluminense. JBras Doenças SexTransm [Internet]. 2000 [cited 2020 Sep 8];12(2):5-12. Available from: http://www.dst.uff.br

3. Menezes ML. Validação do fluxograma de corrimento vaginal em gestantes [tese].Campinas, SP: Faculdade de Ciências Médicas da Universidade Estadual de Campinas; 2003. Available from: http://www. dst.uff.br/revista16-1-2004/6.pdf

4. Spence D, Melville C. Vaginal discharge. BMJ [Internet]. 2007Nov [cited 2020 Sep 8];335(7630):1147-51. Available from: https://doi. org/10.1136/bmj.39378.633287.80

5. Passos MR, Appolinario MA, Varella RQ. Atendimento de gestantes numa clínica de DST. JBrasDoenças SexTransm [Internet]. 2003 [cited 2020 Sep 08]; 15(1): 23-9. Available from: http://www.dst.uff.br

6. Behets FM, Ward E, Fox L, Reed R, Spruyt A, Bennett, et al. Sexually transmitted diseases are common in women attending Jamaican family planning clinics and appropriate detection tolls are lacking. Sex Transm Inf [Internet]. 1998 Jun [cited 2020 Sep 8];74(Suppl 1):S123-7. Available from: https://pubmed.ncbi.nlm.nih.gov/10023362/

7. Costello Daly C, Wangel AM, Hoffman IF, Canner JK, Lule GS, Lema $\mathrm{VM}$, et al. Validation of the WHO diagnosis algorithm and development of an alternative scoring system for management of women presenting with vaginal discharge in Malawi. Sex Transm Inf [Internet]. 1998 Jun [cited 2020 Sep 8];74(Suppl 1):S50-8. Available from: https://pubmed.ncbi.nlm.nih. gov/10023354/

8. Goje O, Munoz JL. Vulvovaginitis: find the cause to treat it. Cleveland JMed [Internet]. 2017 Mar [cited 2020 Sep 8];84(3):215-24. Available from: https://doi.org/10.3949/ccjm.84a.15163

9. Eleutério Júnior J, Ferreira RN, Freitas SF, Rodrigues FE, Moreira JC. Vaginosecitolítica: novos conceitos. Femina. 1995;23(5):423-4.

10. Holland J, Young M, Lee O. Vulvovaginal carriage of yeasts other than Candida albicans. SexTransmInfect [Internet]. 2003 [cited 2020 Sep 8];79(3):249-50. Available from: http://dx.doi.org/10.1136/sti.79.3.249

11. Sobel JD. Vulvovaginal candidosis. Lancet [Internet]. 2007Jun [cited 2020 Sep 8];369(9577):1961-71. Available from: https://doi.org/10.1016/ S0140-6736(07)60917-9

12. Sobel JD, Wiesenfeld HC, Martens M, Danna P, Hooton TM, Rompalo A, et al. Maintenance fluconazole therapy for recurrent vulvovaginal candidiasis. NEngl J Med [Internet]. 2004 Aug [cited 2020 Sep 8];351(9):876-83. Available from: https://doi.org/10.1056/nejmoa033114

13. Nasioudis D, Linhares IM, Ledger WJ, Witkin SS. Bacterial vaginosis: a critical analysis of current knowledge. BJOG [Internet]. 2017 Jan [cited 2020 Sep 8];124(1):61-9. Available from: $\underline{\text { https://doi.org/10.1111/1471-0528.14209 }}$

14. Marconi C, El-Zein M, Ravel J, Ma B, Lima MD, Carvalho NS, et al. Characterization of the vaginal microbiome in women of reproductive age from five regions in Brazil. SexTransm Dis [Internet]. 2020 Aug [cited 2020 Sep 8];47(8):562-9. Available from: https://doi.org/10.1097/ olq. 0000000000001204

15. Graves KJ, Ghosh AP, Kissinger PJ, Muzny CA. Trichomonas vaginalis virus: a review of the literature. Int J STD AIDS [Internet]. 2019 Apr [cited 2020 Sep 8];30(5):496-504. Available from: https://doi. org/10.1177/0956462418809767

16. Edwards T, Burke P, Smalley H, Hobbs G. Trichomonasvaginalis: clinical relevance, pathogenicity and diagnosis.Crit Rev Microbiol [Internet]. 2016 May [cited 2020 Sep 8];42(3):406-17. Available from: https://doi.org/10.3109/1040841x.2014.958050 
17. Yang S, Zhang Y, Liu Y, Wang J, Chen S, Li S. Clinical significance and characteristics clinical differences of cytolytic vaginoses in recurrent vulvovaginitis. Gynecol Obstet Invest [Internet]. 2017 [cited 2020 Sep 8];82(2):137-43. Available from: https://doi.org/10.1159/000446945

18. Soares R, Vieira-Baptista P, Tavares S. Cytolyticvaginosis: an underdiagnosed pathology that mimics vulvovaginal candidiasis. Acta Obstet Ginecol Port [Internet]. 2017Jun [cited 2020 Sep 8];11(2):106-12. Available from: http://www.scielo.mec.pt/pdf/aogp/v11n2/v11n2a07.pdf

19. Sobel JD, Subramanian C, Foxman B, Fairfax M, Gygax SE. Mixed vaginitis-more than coinfection and with therapeutic implications. CurrInfectDis Rep [Internet]. 2013 Apr [cited 2020 Sep 8];15(2):104-8. Available from: https://doi.org/10.1007/s11908-013-0325-5

20. Eleutério Júnior J, Passos MRL, Giraldo PC, Linhares IM, Carvalho NS. Estudo em citologia em meio líquido (SurePath) da associação de Candida sp. em mulheres com diagnóstico de vaginose bacteriana. JBrasDoenças SexTransm [Internet]. 2012 [cited 2020 Sep 8];24(2):1223. Available from: https://doi.org/10.5533/DST-2177-8264-201224211

21. Centers for Disease Control and Prevention - CDC. STD treatment guidelines: diseases characterized by vaginal discharge [Internet]. Washington, D.C.: CDC; 2015 [cited 2020 Sep 4]. Available from: https://www.cdc.gov/std/tg2015/vaginal-discharge.htm

22. Ministério da Saúde (BR). Secretaria de Vigilância em Saúde. Departamento de Doenças de Condições Crônicas e Infecções Sexualmente Transmissíveis. Protocolo clínico e diretrizes terapêuticas para atenção integral às pessoas com infecções sexualmente transmissíveis (IST) [Internet]. Brasília: Ministério da Saúde; 2020 [cited 2020 Sep 4]. 248 p. Available from: http://www.aids.gov.br/pt-br/pub/2015/protocolo-clinicoe-diretrizes-terapeuticas-para-atencao-integral-pessoas-com-infeccoes

23. Gillet E, Meys JF, Verstraelen H, Bosire C, De Sutter P, Temmerman $\mathrm{M}$, et al. Bacterial vaginosis is associated with uterine cervical human papillomavirus infection: a meta-analysis. BMC Infect Dis [Internet]. 2011 Jan [cited 2020 Sep 8];11:10. Available from: https://doi. org/10.1186/1471-2334-11-10

24. Hillier SL. Diagnosis microbiology of bacterial vaginosis. Am J Obstet Gynecol [Internet]. 1993Aug [cited 2020 Sep 8];169(2 Pt 2):455-9. Available from: https://doi.org/10.1016/0002-9378(93)90340-o

25. Sood S, Kapil A. An update on trichomonas vaginalis. Indian J Sex Transm Dis [Internet]. 2008 [cited 2020 Sep 8];29(1):7-14. Available from: http://www.ijstd.org/article.asp?issn=2589-0557; year=2008; volu $\underline{m e}=29 ;$ issue $=1$; page $=7$; epage $=14$; aulast $=$ Sood

26. Allsworth JE, RatnerJA, Peipert JF. Trichomoniasis and other sexually transmitted infections: results from the 2001-2004 National Health and Nutrition Examination Surveys. Sex Transm Dis [Internet]. 2009 Dec [cited 2020 Sep 8];36(12):738-44. Available from: https://doi.org/10.1097/olq.0b013e3181b38a4b

27. Mann JR, McDermott S, Gill T. Sexually transmitted infection is associated with increased risk of preterm birth in South Carolina women insured by Medicaid. J Matern Fetal Neonatal Med [Internet]. 2010 Jun [cited 2020 Sep 8];23(6):563-8. Available from: https://doi. org/10.3109/14767050903214574

28. Hainer BL, Gibson MV. Vaginitis: diagnosis and treatment. Am Fam Physician [Internet]. 2011 Apr [cited 2020 Sep 8];83(7):807-15. Available from: https://www.aafp.org/afp/2011/0401/p807.html

29. Paladine HL, Desai UA. Vaginitis: diagnosis and treatment. Am Fam Physician [Internet].2018 Mar [cited 2020 Sep 8];97(5):321-9. Available from: https://www.aafp.org/afp/2018/0301/p321.html

30. Pappas PG, Kauffman CA, Andes D, Benjamin DK Jr, Calandra TF, Edwards JE Jr, et al. Clinical practice guidelines for the management of candidiasis: 2009 update the Infectious Diseases Society of America. Clin Infect Dis [Internet]. 2009 Mar [cited 2020 Sep 8];48(5):503-35. Available from: https://doi.org/10.1086/596757
31. Amsel R, Totten PA, Spiegel CA, Chen KC, Eschenbach D, Holmes KK. Nonspecific vaginitis: diagnosis criteria and microbial and epidemiologic associations. Am J Med [Internet]. 1983 Jan [cited 2020 Sep 8];74(1):1422. Available from: https://doi.org/10.1016/0002-9343(83)91112-9

32. Nugent RP, Krohn MA, Hillier SL. Reliability of diagnosing bacterial vaginosis is improved by a standardized method of gram stain interpretation. J Clin Microbiol [Internet]. 1991 Feb [cited 2020 Sep 8];29(2):297-301. Available from: https://www.ncbi.nlm.nih.gov/pmc/ articles/PMC269757/

33. van Schalkwyk J, Yudin MH, Infectious Diseases Committee. Vulvovaginitis: screening for and management of trichomoniasis, vulvovaginal candidiasis, and bacterial vaginosis. J Obstet Gynaecol Can [Internet]. 2015 Mar [cited 2020 Sep 8];37(3):266-74. Available from: https://doi.org/10.1016/s1701-2163(15)30316-9

34. Haefner HK. Current evaluation and management of vulvovaginitis. Clin Obstet Gynecol [Internet]. 1999 Jun [cited 2020 Sep 8];42(2):18495. Available from: https://doi.org/10.1097/00003081-199906000-00004

35. Kusters JG, Reuland EA, Bouter S, Koenig P, Dorigo-Zetsma JW. A multiplex real-time PCR assay for routine diagnosis of bacterial vaginosis. Eur J Clin Microbiol Infect Dis [Internet]. 2015 Sep [cited 2020 Sep 8];34(9):1779-85. Available from: https://doi.org/10.1007/ $\underline{\mathrm{s} 10096-015-2412-\mathrm{z}}$

36. Schwebke JR, Gaydos CA, Nyirjesy P, Paradis S, Kodsi S, Cooper CK. Diagnosis performance of a molecular test versus clinician assessment of vaginitis. J Clin Microbiol [Internet]. 2018 May [cited 2020 Sep 8];56(6):e00252-18. Available from: https://dx.doi. org/10.1128\%2FJCM.00252-18

37. Srinivasan S, Fredricks DN. The human vaginal bacterial biota and bacterial vaginosis. Interdiscip Perspect Infect Dis [Internet]. 2008 Feb [cited 2020 Sep 8]:750479. Available from: https://dx.doi. org $/ 10.1155 \% 2$ F $2008 \% 2$ F 750479

38. Cibley LJ, Cibley LJ. Cytolytic vaginosis. Am J Obstet Gynecol [Internet]. 1991 Oct [cited 2020 Sep 8];165(4 Pt 2):1245-9. Available from: https://doi.org/10.1016/S0002-9378(12)90736-X

39. Eleuterio Júnior J, Eleuterio RMN, Martins LA, Giraldo PC, Gonçalves AKS. Inflammatory cells in liquid-based cytology smears classified as bacterial vaginosis.Diagn Cytopathol [Internet]. 2017 Dec [cited 2020 Sep 8]; 45(12):1100-04. Available from: https://doi. org/10.1002/dc. 23830

40. Eleutério Júnior J, Eleuterio RMN, Valente ABGV, Queiroz FS, Gonçalves AKS, Giraldo PC. Comparison of BD affirm VPIII with gram and liquid-based cytology for diagnosing bacterial vaginoses, candidiasis, and Trichomonas. Clin Exp Obstet Gynecol [Internet]. 2019 Mar [cited 2020 Sep 8];66(1):32-5. Available from: https://doi. org/10.1309/AJCP7TBN5VZUGLZU

41. Machado D, Castro J, Palmeira-de-Oliveira A, Martinez-de-Oliveira $\mathrm{J}$, Cerca N, et al. Bacterial vaginosis biofilms: challenges to current therapies and emerging solutions. Front Microbiol [Internet].2016 Jan [cited 2020 Sep 8];6:1528-41. Available from: https://doi.org/10.3389/ fmicb.2015.01528

42. Bradshaw CS, Morton AN, Hocking J, Garland SM, Morris MB, Moss LM, et al. High recurrence rates of bacterial vaginosis over the course of 12 months after oral metronidazole therapy and factors associated with recurrence. J Infect Dis [Internet]. 2006 Jun [cited 2020 Sep 8];193(11):1478-86. Available from: https://doi.org/10.1086/503780

43. Peterman TA, Tian LH, Metcalf CA, Satterwhite CL, Malotte CK, DeAugustine N, et al. High incidence of new sexually transmitted infections in the year following a sexually transmitted infection: a case for rescreening. Ann Intern Med [Internet]. 2006 Oct [cited 2020 Sep 8];145(8):564-72. Available from: https://doi.org/10.7326/0003-4819-145-8-200610170-00005 
44. Kissinger P. Trichomonasvaginalis: a review of epidemiologic, clinical and treatment issues. BMC Infect Dis [Internet]. 2015 Aug [cited 2020 Sep 8];15:307. Available from: https://doi.org/10.1186/s12879-015-1055-0

45. Kissinger P, Secor WE, Leichliter JS, Clark RA, Schmidt N, Curtin E, et al. Early repeated infections with Trichomonasvaginalis among HIV-positive and HIV-negative women. Clin Infect Dis [Internet]. 2008 Apr [cited 2020 Sep 8];46(7):994-9. Available from: https://dx.doi. org/10.1086\%2F529149

46. Blostein F, Levin-Sparenberg E, Wagner J, Foxman B. Recurrent vulvovaginal candidiasis. Ann Epidemiol [Internet]. 2017Sep [cited 2020 Sep 8];27(9):575-82. Available from: https://doi.org/10.1016/j. annepidem.2017.08.010

47. Sobel JD. Genital candidiasis. Medicine [Internet]. 2014Jun [cited 2020 Sep 8];42(7):364-8. Available from: https://doi.org/10.1016/j. mpmed.2014.04.006
48. Wendel KA, Workowski KA. Trichomoniasis: challenges to appropriate management.Clin Infect Dis [Internet]. 2007 Apr [cited 2020 Sep 8];44(Suppl 3):S123-9. Available from: https://doi.org/10.1086/511425

49. Brocklehurst P, Gordon A, Heatley E, Milan SJ. Antibiotics for treating bacterial vaginosis in pregnancy.Cochrane Database Syst Rev [Internet].2013 Jan [cited 2020 Sep 8];1:CD000262. Available from: https://doi.org/10.1002/14651858.cd000262.pub4

50. Foxman B, Wen A, Srinivasan U, Goldberg D, Marrs CF, Owen J, et al. Mycoplasma, bacterial vaginosis-associated bacteria BVAB3, race, and risk of preterm birth in a high-risk cohort.Am J Obstet Gynecol [Internet]. 2014 Mar [cited 2020 Sep 8];210(3):226.el-7. Available from: https://doi.org/10.1016/j.ajog.2013.10.003

51. Reda S, Gonçalves FA, Mazepa MM, Carvalho NS. Women infected with HIV and the impact of associated sexually transmitted infections. Int J Gynaecol Obstet [Internet]. 2018Aug [cited 2020 Sep 8];142(2):1437. Available from: https://doi.org/10.1002/ijgo.12507 